\title{
Burnout among nursing students: predictors and association with empathy and self-efficacy
}

\author{
Burnout em estudantes de Enfermagem: preditores e associação com empatia e autoeficácia \\ Burnout en estudiantes de enfermería: predictores y asociación con empatía y autoeficacia
}

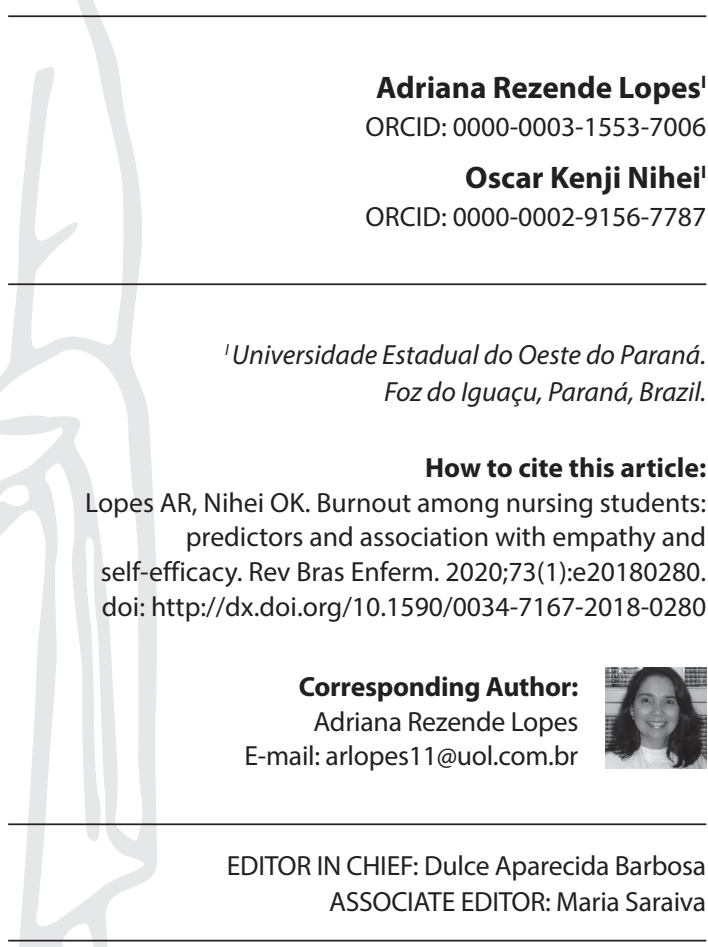

Submission: $05-10-2018$

Approval: 09-23-2018

\begin{abstract}
Objective: to analyze burnout, its predictors and association with empathy and self-efficacy among nursing students. Method: cross-sectional analytical study with 284 students from five state universities in the state of Parana, Brazil. The instruments applied were: social and academic questionnaire, Maslach Burnout Inventory, Interpersonal Reactivity Index and Occupational Self-Efficacy Scale (Short Form). Spearman's correlation and univariate and multivariate logistic analysis were used. Results: $6.0 \%$ of the students presented high burnout, $36.3 \%$ presented high emotional exhaustion, $37.7 \%$ presented high depersonalization and $28.2 \%$ presented low personal accomplishment. The burnout predictors were: absence of physical activity; weekly workload $>24$ hours; low empathic concern. There were negative correlations between empathy (empathic concern and perspective taking) and depersonalization; self-efficacy and emotional exhaustion; and positive correlations between personal accomplishment and empathy and self-efficacy. Conclusion: Personal factors and an academic variable were burnout predictors among nursing students. The correlations suggest that self-efficacy and empathy can prevent burnout.

Descriptors: Burnout, Psychological; Empathy; Self Efficacy; Students, Nursing; Education, Nursing.
\end{abstract}

\section{RESUMO}

Objetivo: Analisar burnout, preditores e associação com empatia e autoeficácia em estudantes de Enfermagem. Método: Estudo transversal, analítico, com 284 estudantes de cinco universidades estaduais paranaenses, aplicando questionário sócio-acadêmico, Maslach Burnout Inventory, Escala Multidimensional de Reatividade Interpessoal e Escala de Autoeficácia Ocupacional - Versão Breve. Foram utilizadas correlação de Spearman e análise logística univariada e multivariada. Resultados: $6,0 \%$ dos estudantes apresentaram alto burnout, 36,3\% alta exaustão emocional, 37,7\% alta despersonalização e $28,2 \%$ baixa realização pessoal. Foram preditores do burnout ausência de atividade física, carga horária semanal de estágio > 24 horas, baixa consideração empática. Houve correlações negativas entre empatia (consideração empática e tomada de perspectiva) e despersonalização, autoeficácia e exaustão emocional, além de correlações positivas da empatia e autoeficácia com a realização pessoal. Conclusão: Fatores pessoais e uma variável acadêmica foram preditoras para burnout em estudantes de Enfermagem. As correlações sugerem que autoeficácia e empatia podem atuar na prevenção burnout.

Descritores: Esgotamento Psicológico; Empatia; Autoeficácia; Estudantes de Enfermagem; Educação em Enfermagem.

\section{RESUMEN}

Objetivo: analizar burnout, predictores y asociación con empatía y autoeficacia en estudiantes de Enfermería. Método: estudio transversal, analítico, con 284 estudiantes de cinco universidades estaduales paranaenses, aplicando: cuestionario socio-académico, Maslach Burnout Inventory, Escala Multidimensional de Reactividad Interpersonal y Escala de Autoeficacia Ocupacional. Se utilizaron correlación de Spearman y análisis logístico univariado y multivariado. Resultados: $6,0 \%$ de los estudiantes presentaron alto burnout, $36,3 \%$ alto agotamiento emocional, $37,7 \%$ alta despersonalización y $28,2 \%$ baja realización personal. Fueron predictores del burnout: ausencia de actividad física; carga horaria semanal de prácticas $>24$ horas; baja consideración empática. Hubo correlaciones negativas entre empatía (consideración empática y toma de perspectiva) y despersonalización; autoeficacia y agotamiento emocional; y correlaciones positivas de la empatía y autoeficacia con la realización personal. Conclusión: factores personales y una variable estudiantil fueron predictores para burnout en estudiantes de Enfermería. Las correlaciones sugieren que autoeficacia y empatía pueden actuar en la prevención de burnout.

Descriptores: Agotamiento Psicológico; Empatía; Autoeficacia; Estudiantes de Enfermería; Educación en Enfermería. 


\section{INTRODUCTION}

The responsibilities, the workload and the physical and psychological demands inherent in nursing work have been associated with vulnerability to burnout ${ }^{(1-2)}$, a psychological syndrome that occurs in response to chronic emotional and interpersonal stressors on the working environment and that results in emotional exhaustion, indifference to others and job dissatisfaction ${ }^{(3-4)}$. National and international studies have focused on burnout among students in the area of health, specially medical ${ }^{(5-7)}$ and nursing students ${ }^{(8-11)}$, and the levels of burnout found are alarming, since this syndrome can affect professional growth, put patient safety at risk and generate consequences to the physical and mental health of the student, such as: sleep disturbances, depressive symptoms and suicidal ideation, alcohol and other drug abuse ${ }^{(4-6,12)}$.

On the other hand, empathy (ability to put oneself in someone else's shoes) has been considered an essential component of quality health care ${ }^{(13-15)}$. It is a skill that helps the professional to understand the situation and the feelings of patients, affecting the accuracy of diagnosis, communication skills, patient satisfaction and adherence to recommended treatment, clinical outcomes and job satisfaction ${ }^{(14-15)}$.

In order to understand the possible associations between burnout and empathy, studies have formulated three hypotheses still to be proven: burnout is an empathy killer, empathy creates burnout, and empathy prevents burnout ${ }^{(16)}$. Although apparently conflictive, these hypotheses suggest that different types of empathy could yield different outcomes regarding burnout, since empathy can be cognitive, affective or composed by both ${ }^{(16)}$. A review of studies with physicians and nurses in international literature concluded that there is consistent evidence for a negative association between burnout and empathy ${ }^{(13)}$, in agreement with other studies with professionals $\mathrm{s}^{(8,7)}$ and students ${ }^{(7-8,18)}$.

Work self-efficacy, which is defined as the belief in one's efficacy to manage tasks, challenges and stresses of their work ${ }^{(19)}$, has been pointed out as a protection factor for burnout among professionals ${ }^{(19-21)}$ and students ${ }^{(22)}$. A study showed that nurses who score high in self-efficacy scores were more likely to overcome problems, frustrations and obstacles, and were less inclined to rumination, energy depletion and loss of motivation ${ }^{(21)}$.

Despite of the studies on the association between burnout and empathy, and between burnout and self-efficacy, no national studies on such associations among nursing students were found. The association between burnout, empathy and self-efficacy was not found in national and international literature. Therefore, to our knowledge, this is the first study to investigate the association between burnout, empathy and self-efficacy, as well as to investigate the predictors of burnout and its dimensions among nursing students.

\section{OBJECTIVE}

To analyze burnout and its predictor variables, as well as the association between burnout, empathy and self-efficacy among third year and up undergraduate nursing students from universities in the state of Paraná, aiming to test the hypothesis that burnout is negatively associated with empathy and self-efficacy.

\section{METHOD}

\section{Ethical aspects}

The project was approved by the Research Ethics Committee of the Western Paraná State University and received authorization from those responsible for the fields of study. After being informed of the voluntary character of their participation and of the guarantee of anonymity, the participants confirmed their acceptance by signing the Informed Consent Form.

\section{Design, study setting and period}

A quantitative, cross-sectional and analytical study with students from 6 full-time nursing undergraduate programs from 5 state public universities located in 6 cities of Parana, Brazil: State University of Londrina (UEL); State University of Maringá (UEM); Midwestern State University (UNICENTRO), Guarapuava Campus; Western Paraná State University (UNIOESTE), Cascavel and Foz do Iguaçu Campi; University of the State of Paraná (UNESPAR), Paranavaí Campus. Data was collected during the first semester of the academic calendar, from June to September 2017.

\section{Population and sample: inclusion criteria}

The present research used convenience sampling. Of the total 416 eligible students enrolled in the third, fourth and fifth years, $323(77.6 \%)$ participated. There was a loss of $12.1 \%$ due to errors completing the scales. The final sample was composed of 284 students ( $68.3 \%$ of those enrolled).

The inclusion criteria for the nursing programs was having a pedagogical program that established supervised practical activities from the third year and having those activities in the semester of the data collection. The inclusion criteria for the students were: being enrolled in the years studied; being 18 years old or over.

\section{Study protocol}

Data was collected by the researchers or collaborators in the classrooms, except for the groups that were only in the internship site. These classes were approached during meetings with supervisors or course coordinators and, in the absence of such meetings, the students received e-mails with links to the online instruments on the Surveymonkey ${ }^{\circ}$ platform. Most of the sample (87.3\%) filled in paper instruments. The data obtained in the paper instruments were typed in an Excel spreadsheet by the researcher and double-checked by research collaborators.

Participants completed a questionnaire containing social and academic variables, and 3 self-applied scales: Maslach Burnout Inventory (MBI), the Interpersonal Reactivity Index of Davis (EMRI) and Occupational Self-Efficacy Scale - Short Form (OSS-SF). The variables obtained in the questionnaire were: gender, date of birth, civil status, presence of children, family income, weekly hours of the internship (the term internship represents, in the present study, the supervised practical activities and the supervised internship), on-site internship time, employment beyond the internship, physical activity, leisure activity, and chronic illness. 
The burnout inventory used was the $\mathrm{MBI}^{(23)}$ in the version validated for Portuguese ${ }^{(24-25)}$. The inventory has 22 statements on a 5-point Likert scale ${ }^{(25)}$ distributed in three subscales: emotional exhaustion (feeling of physical and mental depletion), depersonalization (cold and impersonal contact with patients) and personal accomplishment (feeling of competence and success in working with people). Cut-off scores were calculated with percentile 75 (emotional exhaustion and depersonalization) and 25 (personal accomplishment), as used by Lautert ${ }^{(24)}$. The cut-off scores for high burnout in the sample were: emotional exhaustion $\geq 27$, depersonalization $\geq 10$, personal accomplishment $\leq 26$.

The EMRI ${ }^{(26)}$ is the Brazilian validation of the Interpersonal Reactivity Index ${ }^{(27)}$, used to evaluate empathy, composed of 21 statements on a 5-point Likert scale, distributed in three subscales: empathic concern (emotional empathy, inclination to worry about other people's difficulties), perspective taking (cognitive empathy, ability to adopt other people's point of view, predicting behaviors and actions) and personal distress (anguish, aversive behavior and a sense of anxiety about the misfortune of others) ${ }^{(26-27)}$.

The OSS-SF ${ }^{(28)}$ is the Brazilian validation of the Occupational SelfEfficacy Scale - Short Form ${ }^{(29)}$, used to evaluate work self-efficacy, with six five-point Likert statements ${ }^{(28-29)}$.

The reliability of the instruments was verified by the Cronbach alpha coefficient. The alpha values for the sample were: MBI (emotional exhaustion $=0.825$; depersonalization $=0.613$; personal accomplishment $=0.693$ ); EMRI (empathic concern $=0.635$; perspective taking $=0.691$; personal distress $=0.716$ ); OSS-SF $=0.775$.

\section{Analysis of results and statistics}

\section{A descriptive and inferential statistical}

analysis was conducted using the Minitab program (version 18.1, 2017 ), considering a significance level $a<0.05$. Normality of the data was verified by the Kolmogorov-Smirnov test. The dependent variables were: high burnout, high emotional exhaustion, high depersonalization and reduced personal accomplishment. The independent variables were: the empathy subscales, self-efficacy and social and academic data. The predictor variables were determined by multivariate logistic regression (forward method, logit function, $95 \%$ confidence interval, $a<0.05$ ), and the variables that obtained $\mathrm{p} \leq 0.20$ in the univariate logistic regression were included in the multivariate model. The fitness of the regression model was assessed by the Pearson and Hosmer-Lemeshow tests, and the sensitivity and specificity of the model was assessed by the analysis of the area under the ROC (Receiver Operating Characteristic) curve, considering acceptable discrimination $0.7 \leq \mathrm{ROC}<0.8^{(30)}$. VIF (Variance Inflation Factor) was used to detect multicollinearity, considering absence if $\mathrm{VIF}=1$. Differences in central tendency of the scores of the scales and subscales were evaluated by the T-student, Mann-Whitney, ANOVA or Kruskal-Wallis tests. The correlations between the scores of the scales were verified by the Spearman correlation coefficient, considering: 0 (absence), 0.1-0.3 (weak), 0.4-0.6 (moderate), 0.7-0.9 (strong) and 1 (perfect).

\section{RESULTS}

The majority of the sample was composed of female students (90.1\%), between 18 and 24 years old $(77.5 \%)$, single (83.8\%), without children (88.7\%), with no employment beyond the internship (76.8\%), who do not live alone $(84.5 \%)$, with family income less than or equal to 3 minimum wages (56.0\%), who engage in leisure activities (71.5\%) and do not engage in regular physical activity (66.2\%), with no chronic disease (85.2\%), with a weekly workload in the internship of up to 24 hours (58.1\%) and who have been working in the internship site for less than three months (84.5\%).

The prevalence of high burnout among the nursing students surveyed was $6.0 \%$. In relation to the burnout subscales, $36.3 \%$ of the students presented high emotional exhaustion, $37.7 \%$ presented high depersonalization, $28.2 \%$ presented reduced personal accomplishment and $33.1 \%$ had no change in the 3 subscales.

The comparison between the students'scores on the empathy subscales and on the self-efficacy scale in relation to the presence or absence of high burnout showed that those with high burnout had statistically higher scores in personal distress and lower scores in empathic concern and perspective taking (Table 1).
Table 1 - Comparison of results of the subscales of the Multidimensional Interactional Reactivity Scale and of the Occupational Self-Efficacy Scale - Brief Version, in relation to high burnout in nursing students, Paraná, Brazil, 2017

\begin{tabular}{|c|c|c|c|c|c|c|c|}
\hline \multirow{3}{*}{ Variable } & \multicolumn{6}{|c|}{ High burnout } & \multirow{3}{*}{$\boldsymbol{p}^{*}$} \\
\hline & & No & & & Yes & & \\
\hline & Mean & SD & Median & Mean & SD & Median & \\
\hline Empathic Concern & 27.3 & 4.4 & 28 & 24.1 & 5.0 & 25 & $0.011^{\S}$ \\
\hline Perspective Taking & 26.3 & 4.5 & 26 & 24.2 & 3.0 & 24 & $0.032^{\S}$ \\
\hline Personal Distress & 18.6 & 4.9 & 18 & 20.8 & 5.5 & 21 & $0.032^{\S}$ \\
\hline Self-efficacy & 22.8 & 4.3 & 24 & 20.6 & 5.2 & 22 & 0.092 \\
\hline
\end{tabular}

Emotional exhaustion showed weak correlations: a positive correlation with depersonalization and personal distress; and a negative correlation with personal accomplishment and self-efficacy. There was a weak negative correlation between depersonalization and personal accomplishment. Empathic concern and perspective taking had a weak positive correlation between them, and both had other weak correlations: negative with depersonalization; positive with personal accomplishment. Personal distress and personal accomplishment had a weak negative correlation. Selfefficacy showed two moderate correlations: a positive correlation with personal accomplishment and a negative correlation with personal distress. In addition, there was a weak positive correlation between self-efficacy and perspective taking (Table 2).

Univariate logistic regression was performed for high burnout, high emotional exhaustion, high depersonalization and low personal accomplishment in relation to variables: gender (male; female), age (18-24 years old; $>24$ years), civil status (single/divorced; stable union/married), children (yes; no), income ( $\leq 3$ minimum wages; $>3$ minimum wages), weekly hours in the internship ( $\leq 24$ hours; $>24$ to 40 hours), time in the internship ( $\leq 3$ months; $>3$ months), employment (yes; no), physical activity (yes; no), leisure activity (yes; no), subscales of empathy and self-efficacy. For high burnout, 
the variables that presented $p<0.20$ in the univariate analysis and were included in the multivariate analysis were: weekly workload, physical activity, empathic concern, perspective taking, personal distress and self-efficacy. A weekly workload of more than 24 hours, lack of regular physical activity and lower scores of empathic concern were predictors of high burnout (Table 3).

Table 2 - Spearman correlation coefficients between the dimensions of the Maslach Burnout Inventory, the dimensions of the Interpersonal Reactivity Index and the dimension of the Occupational Self-Efficacy Scale, Paraná, Brazil, 2017

\begin{tabular}{|c|c|c|c|c|c|c|c|}
\hline Variables & EE & DE & PA & EC & Pt & PD & SE \\
\hline Emotional Exhaustion (EE) & 1 & & & & & & \\
\hline Depersonalization (DE) & $0.160^{*}$ & 1 & & & & & \\
\hline Personal Accomplishment (PA) & $-0.247^{\S}$ & $-0.215^{\S}$ & 1 & & & & \\
\hline Empathic Concern (EC) & 0.004 & $-0.312^{\S}$ & $0.178^{*}$ & 1 & & & \\
\hline Perspective Taking (PT) & -0.064 & $-0.218^{\S}$ & $0.178^{*}$ & $0.336^{\S}$ & 1 & & \\
\hline Personal Distress (PD) & $0.195^{*}$ & 0.095 & $-0.270^{\S}$ & 0.109 & -0.054 & 1 & \\
\hline Self-Efficacy (SE) & $-0.214^{\S}$ & -0.105 & $0.428^{\S}$ & 0.003 & $0.135^{*}$ & $-0.441^{\S}$ & 1 \\
\hline
\end{tabular}

Table 3 - Univariate and multivariate logistic regression of independent variables in relation to high burnout among nursing students, Paraná, Brazil, 2017

\begin{tabular}{|c|c|c|c|c|}
\hline \multirow{2}{*}{ Variable } & \multicolumn{2}{|c|}{ Univariate regression } & \multicolumn{2}{|c|}{ Multivariate regression* } \\
\hline & OR $(95 \% \mathrm{Cl})$ & $p$ & OR $(95 \% \mathrm{Cl})$ & $p$ \\
\hline Gender $^{1}$ & $0.556(0.071-4.355)$ & 0.544 & & \\
\hline $\mathrm{Age}^{2}$ & $0.479(0.106-2.158)$ & 0.298 & & \\
\hline Civil status ${ }^{3}$ & $0.365(0.047-2.834)$ & 0.267 & & \\
\hline Children ${ }^{4}$ & $1.053(0.230-4.833)$ & 0.947 & & \\
\hline Family income $e^{5}$ & $1.170(0.438-3.126)$ & 0.755 & & \\
\hline Weekly workload ${ }^{6}$ & $2.830(1.015-7.889)$ & $0.041^{\S}$ & $2.939(1.025-8.429)$ & 0.040 \\
\hline Time in the internship ${ }^{7}$ & $0.536(0.068-4.209)$ & 0.518 & & \\
\hline Employment ${ }^{4}$ & $0.694(0.193-2.492)$ & 0.562 & & \\
\hline Physical activity ${ }^{4}$ & $0.245(0.055-1.096)$ & $0.031^{\S}$ & $0.208(0.045-0.956)$ & 0.018 \\
\hline Leisure activity ${ }^{4}$ & $0.697(0.249-1.954)$ & 0.500 & & \\
\hline Empathic concern & $0.865(0.779-0.961)$ & $0.007^{\S}$ & $0.866(0.778-0.965)$ & 0.001 \\
\hline Perspective taking & $0.902(0.808-1.006)$ & $0.063^{\S}$ & & \\
\hline Personal distress & $1.096(0.992-1.211)$ & $0.068^{\S}$ & & \\
\hline Self-efficacy & $0.896(0.806-0.995)$ & $0.044^{\S}$ & & \\
\hline
\end{tabular}

For high emotional exhaustion, the variables included in the multivariate logistic regression were: age, weekly workload, physical activity, leisure activity, personal distress and selfefficacy. Age between 18 and 24, a weekly workload of more than 24 hours, lack of physical activity and lower self-efficacy scores were predictors of high emotional exhaustion. For high depersonalization, the variables included in the multivariate logistic regression were: gender, civil status, leisure activity, empathic concern, perspective taking and self-efficacy. Lack of leisure activities and lower scores of empathic concern were predictors of high depersonalization. For reduced personal accomplishment, the variables included in the multivariate logistic regression were: employment, empathic concern, perspective taking, personal distress and self-efficacy. Lower scores of empathic concern and self-efficacy were predictors of reduced personal accomplishment (Table 4).

The scores of burnout, empathy and self-efficacy grouped by the students' undergraduate year were compared. For this analysis, two groups with 3 programs each were formed, one with the 4-year programs and another with the 5-year programs. In the group of 5-year programs there was a statistically significant increase in the median score of depersonalizations between fifth year students (10.0) in relation to fourth year students (7.0) $(p=0.026)$.

Table 4 - Univariate and multivariate logistic regression of independent variables in relation to high emotional exhaustion (hEE), high depersonalization (hDE) and reduced personal accomplishment (rPA), in nursing students, Paraná, Brazil, 2017

\begin{tabular}{lccc}
\hline Subscale: Variable & $\begin{array}{c}\text { Univariate regression } \\
\text { OR (95\%Cl) }\end{array}$ & $\boldsymbol{p}$ & $\begin{array}{c}\text { Multivariate regression* } \\
\text { OR (95\%Cl) }\end{array}$ \\
\hline hEE: Gender $^{1}$ & $0.816(0.355-1.877)$ & 0.630 & \\
Age $^{2}$ & $0.467(0.242-0.901)$ & $0.018^{5}$ & $0.504(0.253-1.004)$ \\
Civil state $^{3}$ & $0.721(0.349-1.487)$ & 0.368 & \\
Children $^{4}$ & $0.777(0.353-1.712)$ & 0.527 & \\
Family income $^{5}$ & $1.009(0.618-1.650)$ & 0.970 & \\
Weekly workload $^{6}$ & $1.759(1.073-2.883)$ & $0.025^{\S}$ & $1.777(1.056-2.988)$ \\
Timein the internship $^{7}$ & $1.180(0.524-2.656)$ & 0.691 & \\
Employment $^{4}$ & $1.094(0.619-1.934)$ & 0.756 & \\
Physical activity $^{4}$ & $0.535(0.313-0.915)$ & $0.020^{5}$ & $0.482(0.273-0.851)$ \\
Leisure activity $^{4}$ & $0.667(0.391-1.135)$ & $0.137^{\S}$ & \\
Empathic concern $_{\text {Perspective taking }}$ & $1.018(0.964-1.075)$ & 0.515 & \\
Personal distress $_{\text {Self-efficacy }}$ & $0.989(0.938-1.044)$ & 0.703 & \\
hDE: Gender $^{1}$ & $1.064(1.012-1.119)$ & $0.014^{\S}$ & \\
Age $^{2}$ & $0.926(0.875-0.979)$ & $0.007^{\S}$ & $0.939(0.884-0.998)$ \\
\hline
\end{tabular}




\begin{tabular}{|c|c|c|c|c|}
\hline \multirow{2}{*}{ Subscale: Variable } & \multicolumn{2}{|c|}{ Univariate regression } & \multicolumn{2}{|c|}{ Multivariate regression* } \\
\hline & OR $(95 \% \mathrm{Cl})$ & $p$ & OR $(95 \% \mathrm{CI})$ & $p$ \\
\hline Civil state ${ }^{3}$ & $0.585(0.279-1.226)$ & $0.144^{\S}$ & & \\
\hline Children $^{4}$ & $0.992(0.464-2.120)$ & 0.983 & & \\
\hline Family income ${ }^{5}$ & $0.999(0.614-1.625)$ & 0.996 & & \\
\hline Weekly workhours ${ }^{6}$ & $1.141(0.698-1.866)$ & 0.598 & & \\
\hline Time in the internship ${ }^{7}$ & $0.673(0.283-1.600)$ & 0.360 & & \\
\hline Employment $^{4}$ & $0.853(0.480-1.516)$ & 0.587 & & \\
\hline Physical activity ${ }^{4}$ & $1.057(0.637-1.754)$ & 0.830 & & \\
\hline Leisure activity ${ }^{4}$ & $0.517(0.304-0.876)$ & $0.014^{\S}$ & $0.469(0.269-0.817)$ & 0.007 \\
\hline Empathic concern & $0.883(0.834-0.935)$ & $0.001^{\S}$ & $0.876(0.826-0.929)$ & 0.0001 \\
\hline Perspective taking & $0.947(0.897-1.000)$ & $0.047^{\S}$ & & \\
\hline Personal distress & $1.027(0.978-1.078)$ & 0.279 & & \\
\hline Self-efficacy & $0.963(0.911-1.018)$ & $0.181^{\S}$ & & \\
\hline rPA: Gender ${ }^{1}$ & $0.836(0.341-2.050)$ & 0.691 & & \\
\hline $\mathrm{Age}^{2}$ & $0.742(0.381-1.444)$ & 0.372 & & \\
\hline Civil status $^{3}$ & $0.962(0.455-2.032)$ & 0.919 & & \\
\hline Kids ${ }^{4}$ & $1.182(0.533-2.621)$ & 0.684 & & \\
\hline Family income ${ }^{5}$ & $1.094(0.649-1.843)$ & 0.736 & & \\
\hline Weekly workload ${ }^{6}$ & $1.297(0.764-2.205)$ & 0.337 & & \\
\hline Time in the internship ${ }^{7}$ & $0.733(0.284-1.897)$ & 0.513 & & \\
\hline Employment $^{4}$ & $0.553(0.282-1.082)$ & $0.073^{\S}$ & & \\
\hline Physical activity ${ }^{4}$ & $0.724(0.413-1.271$ & 0.256 & & \\
\hline Leisure actvity ${ }^{4}$ & $1.132(0.631-2.029$ & 0.677 & & \\
\hline Empathic concern & $0.872(0.820-0.927$ & $0.001^{\S}$ & $0.867(0.812-0.924)$ & 0.0001 \\
\hline Perspective taking & $0.900(0.847-0.956)$ & $0.001^{\S}$ & & \\
\hline Personal distress & $1.102(1.043-1.164)$ & $0.001^{\S}$ & & \\
\hline Self-efficacy. & $0.838(0.785-0.894)$ & $0.001^{\S}$ & $0.831(0.775-0.890)$ & 0.0001 \\
\hline
\end{tabular}

Note: $N=284$. $h E E=$ high emotional exhaustion; $h D E=$ high depersonalization; rRP=reduced personal accomplishment. Odd Ratio (OR) references: ${ }^{1} \mathrm{male} ;{ }^{2}>24$ years; ${ }^{3}$ Married $/$ stable union; ${ }^{4}$ Yes; ${ }^{5}>3$ minimum wages; ${ }^{6} \leq 24$ hours $^{7}>3$ months. ${ }^{\prime h}$ EE: Pearson 0,359; Hosmer-Lemeshow 0.659; ROC 0.68; hDE: Pearson 0.405; Hosmer-Lemeshow 0.216; ROC 0/70; rPA: Pearson 0.210; Hosmer-Lemeshow $0.453 ; R O C 0.75 .{ }^{5} p<0.20$.

\section{DISCUSSION}

Among the nursing students studied, $6.0 \%$ presented high burnout, $36.3 \%$ presented high emotional exhaustion, $37.7 \%$ presented high depersonalization and $28.2 \%$ presented reduced personal accomplishment. A similar prevalence of high burnout was observed in nursing technicians and assistants of a general hospital in a city in the state of Sao Paulo ${ }^{(31)}$, but the percentages of high emotional exhaustion (28.4\%), high depersonalization (31.6\%) and low personal fulfillment (22.9\%) were lower.

Two studies of national scope conducted with medical students, one in $\mathrm{Brazil}^{(7)}$ and the other in the United States ${ }^{(5)}$, found higher levels of high emotional exhaustion (respectively $51.6 \%$ and $44.6 \%$ ) and high depersonalization (respectively $40.4 \%$ and $37.9 \%)$. An American study ${ }^{(5)}$ adopted as criterion for burnout the occurrence of high emotional exhaustion or high depersonalization and obtained a $55.9 \%$ prevalence of high burnout ${ }^{(32)}$. The present study found 163 nursing students with high emotional exhaustion or high depersonalization, which would correspond to $57.4 \%$ of the sample, a percentage close to that found in the North American study.

The percentages of high emotional exhaustion and depersonalization found among students while they first experience the profession require the attention of those responsible for nursing training and point out the need for further investigation into the phenomenon. Emotional exhaustion is the central quality and the most obvious manifestation of burnout ${ }^{(4)}$. It predisposes to the development of burnout, whether during undergraduate studies or in the future, when the person actually enters the job market and takes on the tasks of the job. Likewise, emotional detachment, indifference and cynicism, characteristics of depersonalization $^{(3-4)}$, can cause problems and damage relationships, especially in Nursing, where the essence of work is care and work in multidisciplinary teams.

It is inferred that the percentage of high depersonalization found in the present study could be higher, since $16.5 \%$ of the students chose the option with lower score, corresponding to "never", in all items of this subscale. Scholars defend that the affirmations of this subscale suggest the presence of cold, distant and impersonal contact with the patients, and low scores could result from the avoidance of feelings that are frowned upon in the social and professional environment ${ }^{(33)}$. The humanistic approach to nursing training in $\mathrm{Brazil}^{(34)}$ has a contrary view to that which arises from feelings associated with depersonalization, which could hinder the acceptance of such feelings and generate the reaction of denying them by choosing "never".

Pioneers of the study of burnout suggest that the topic should be included in the preparatory process for health careers, with knowledge and discussion about burnout as part of the educational curriculum ${ }^{(35)}$. Students would benefit from the promotion of discussions in the classroom, where they would be able to express and accept feelings that emerge in the early work experience, and then receive the necessary support for their professional maturity.

The analysis of correlation between the burnout subscales showed that the scores of emotional exhaustion and depersonalization tended to fluctuate in the same direction, while personal accomplishment grew in the opposite direction, corroborating 
the use of the scores of the three subscales for the indication of burnout ${ }^{(4,23-25)}$.

It was observed that the group of students with high burnout obtained a statistically lower median of perspective taking (cognitive empathy) and empathic concern (affective empathy), and a statistically higher median of personal distress, suggesting that burnout could decrease empathy or that the two empathies, affective and cognitive, could act together in burnout prevention ${ }^{(36)}$.

Affective and cognitive empathy were positively correlated with each other, and both were positively correlated with personal accomplishment and negatively correlated with depersonalization, as also shown in a study conducted with Brazilian medical students ${ }^{(7)}$. Thus, the data indicate that greater affective empathy and greater cognitive empathy are associated with less emotional detachment and greater satisfaction with the activities performed.

Emotional exhaustion and personal distress had a weak positive correlation. Therefore, physical and mental exhaustion, characteristics of emotional exhaustion, were associated with anguish regarding other people's distressing situations.

The strongest correlations found involved self-efficacy: when self-efficacy increases, personal accomplishment tends to increase and personal distress to decrease. The correlation between selfefficacy and personal accomplishment was observed in studies with professionals ${ }^{(19-21)}$ and the correlation of self-efficacy with personal distress was observed in a study with Brazilian medical students ${ }^{(7)}$. Thus, confidence in one's own competence seems to be related to increased satisfaction in performing activities or, in another perspective, the greater the personal sense of accomplishment, the greater the perception of self-efficacy. Self-efficacy showed a weak negative correlation with emotional exhaustion. Considering the relevant role of emotional exhaustion in the development of burnout, the results of the present study show an agreement with the negative association between self-efficacy and burnout found in studies with professionals ${ }^{(19-21)}$ and students ${ }^{(22)}$.

Lack of physical activity, a weekly workload of more than 24 hours and lower empathic concern scores were predictors of high burnout. The association between physical activity and lower levels of burnout is also found in recent studies ${ }^{(37-38)}$. As for the weekly workload, only $40.1 \%$ of the students reported working more than 24 hours, which may have favored the low prevalence of high burnout. The fact that low affective empathy is a predictor variable contributes to the hypothesis of its protective role for burnout ${ }^{(13,16)}$.

The variables that predicted emotional exhaustion were lack of physical activity and a weekly workload of more than 24 hours, associated with age between 18 and 24 and lower self-efficacy scores. The vulnerability of younger people to burnout has been reported in several studies ${ }^{(2,4)}$. The stress generated by the responsibility of care tends to be more intense in beginners, who are still inexperienced and less confident, and thus predisposed to emotional exhaustion and burnout.

The lack of leisure activities and lower scores of affective empathy were predictors of high depersonalization. In the present study, $71.5 \%$ of the students reported that they engaged in leisure activities, a number close to $61.3 \%$ of students with low or moderate depersonalization. The relationship between leisure time and lower levels of burnout is in the literature ${ }^{(39)}$.
The increase in depersonalization observed in fifth-year nursing students in relation to fourth-year students is in agreement with a Brazilian cross-sectional study with medical students ${ }^{(7)}$ which found that depersonalization increase occurred during undergraduate studies. However, the study also found increased values of emotional exhaustion, low personal accomplishment and a decrease in empathy, contrasting with the present research which did not find such variations. It is observed that the academic studies were not able to foster an increase of empathy among the students, which indicates that, if the importance of empathy for health care is recognized, there is a need to implement strategies for teaching empathy ${ }^{(15)}$ in undergraduate nursing courses.

The results obtained indicate possible actions for the prevention of burnout and its dimensions in nursing students, such as: adequate distribution of the workload during the course; creation of programs to incentive regular physical and leisure activities; implementation of educational activities aimed at the development of empathy and self-efficacy.

\section{Limitations of the study}

As a limitation of this study, it is worth mentioning that the convenience sampling does not allow generalization of the results for the totality of students enrolled and that there was no possibility to adjust the analysis according to the differences in the pedagogical and political programs of the nursing courses, which could be affecting the level of emotional exhaustion in students. Regarding the multivariate logistic regression analysis, a possible limitation is that reduced sample sizes may lead to lower statistical power; however, the models were acceptable in adjustment, sensitivity and specificity. Another limitation is that the cross-sectional study does not allow verifying whether empathy and self-efficacy prevented burnout or suffered a decline due to burnout. Future longitudinal studies could investigate this condition and the causal relationships of factors influencing burnout, empathy, and self-efficacy during academic studies.

\section{Contributions to the area of nursing, health or public policy}

The present research contributes by presenting the associations between burnout, empathy and self-efficacy, three aspects cited in the literature as capable of influencing the quality of health care, besides presenting predictors of burnout and its dimensions among nursing students. The results allow reflection on possible actions for the prevention of burnout and point out demands for new investigations to improve professional training in nursing.

\section{CONCLUSION}

The prevalence of high burnout among the nursing students surveyed was considered low. However, the percentages of high emotional exhaustion and high depersonalization can predispose to the development of burnout.

The results suggest that increased empathy (cognitive and affective) and self-efficacy may be complementary in the prevention of burnout, as empathy was negatively associated with high burnout and correlated with lower depersonalization, self-efficacy 
was correlated with lower emotional exhaustion, and both were correlated with greater personal accomplishment.

Low scores of empathic concern were identified as predictors of burnout, depersonalization, and reduced personal accomplishment, pointing to the protective character of affective empathy. In addition, the absence of regular physical activity was identified as a predictor of burnout and emotional exhaustion, pointing to the protective character of these activities.

\section{REFERENCES}

1. Silva JLL, Dias AC, Teixeira LR. Discussão sobre as causas da Síndrome de Burnout e suas implicações à saúde do profissional de enfermagem. Aquichan [Internet]. 2012 [cited 2018 Apr 13];12(2):144-59. Available from: http://www.scielo.org.co/scielo.php?script=sci_art text\&pid=S1657-59972012000200006

2. Adriaenssens J, De Gucht V, Maes S. Determinants and prevalence of burnout in emergency nurses: a systematic review of 25 years of research. Int J Nurs Stud. 2015;52(2):649-61. doi: 10.1016/j.ijnurstu.2014.11.004

3. Maslach C, Leiter MP. Understanding the burnout experience: recent research and its implications for psychiatry. World Psychiatry. 2016;15(2):103-11. doi: 10.1002/wps.20311

4. Maslach C, Schaufeli WB, Leiter MP. Job burnout. Annu Rev Psychol. 2001;52:397-422. doi: 10.1146/annurev.psych.52.1.397

5. Dyrbye LN, West CP, Satele D, Boone S, Tan L, Sloan J, et al. Burnout among U.S. medical students, residents, and early career physicians relative to the general U.S. population. Acad Med. 2014;89(3):443-51. doi: 10.1097/ACM.0000000000000134

6. Dyrbye LN, Shanafelt TD. A narrative review on burnout experienced by medical students and residents. Med Educ. 2016;50:132-49. doi: 10.1111/medu.12927

7. Paro HBMS, Silveira PSP, Perotta B, Gannam S, Enns SC, Giaxa RRB, et al. Empathy among medical students: is there a relation with quality of life and burnout? PLoS One. 2014;9(4):e94133. doi: 10.1371/journal.pone.0094133

8. Ferri P, Guerra E, Marcheselli L, Cunico L, Lorenzo, RD. Empathy and burnout: an analytic cross-sectional study among nurses and nursing students. Acta Biomed [Internet]. 2015 [cited 2018 Apr 13];86(Suppl 2):104-15. Available from: https://mattioli1885journals.com/index.php/ actabiomedica/article/download/4792/3529

9. Tomaschewski-Barlem JG, Lunardi VL, Lunardi GL, Barlem ELD, Silveira RS, Vidal DAS. Burnout syndrome among undergraduate nursing students at a public university. Rev Latino-Am Enfermagem. 2014;22(6):934-41. doi: 10.1590/0104-1169.3254.2498

10. Silva RM, Goulart CT, Lopes LFD, Serrano PM, Costa ALS, Guido LA. Hardy personality and burnout syndrome among nursing students in three Brazilian universities: an analytic study. BMC Nurs. 2014;13(1):9. doi: 10.1186/1472-6955-13-9

11. Cavalcanti KCSN, Silva DB, Almeida MP, Aquino JM, Paula JMMSF. Burnout syndrome among undergraduate nursing students in public universities. Rev Enferm UFPE. 2014;8(2):3662-8. doi: 10.5205/reuol.4597-37683-1-ED.0810supl201412

12. Jackson ER, Shanafelt TD, Hasan O, Satele DV, Dyrbye LN. Burnout and alcohol abuse/dependence among U.S. medical students. Acad Med. 2016;91(9):1251-6. doi: 10.1097/ACM.0000000000001138

13. Wilkinson $\mathrm{H}$, Whittington $\mathrm{R}$, Perry L, Eames $\mathrm{C}$. Examining the relationship between burnout and empathy in healthcare professionals: a systematic review. Burn Res. 2017;6:18-29. doi: 10.1016/j.burn.2017.06.003

14. Derksen F, Bensing J, Lagro-Janssen A. Effectiveness of empathy in general practice: a systematic review. Br J Gen Pract. 2013;63(606):e76-e84. doi: 10.3399/bjgp13X660814

15. Stepien KA, Baernstein A. Educating for empathy: A review. J Gen Intern Med. 2006;21:524-30. doi: 10.1111/j.1525-1497.2006.00443.x

16. Zenasni F, Boujut E, Woerner A, Sultan S. Burnout and empathy in primary care: three hypotheses. Br J Gen Pract. 2012;62(600):346-7. doi: 10.3399/bjgp12X652193

17. Yuguero O, Marsal JR, Esquerda M, Vivanco L, Soler-González J. Association between low empathy and high burnout among primary care physicians and nurses in Lleida, Spain. Eur J Gen Pract. 2017;23(1):4-10. doi: 10.1080/13814788.2016.1233173

18. Hojat $M$, Vergare $M$, Isenberg $G$, Cohen $M$, Spandorfer J. Underlying construct of empathy, optimism and burnout in medical students. Int J Med Educ. 2015;6:12-6. doi: 10.5116/ijme.54c3.60cd

19. Shoji K, Cieslak R, Smoktunowicz E, Rogala A, Benight CC, Luszczynska, A. Associations between job burnout and self-efficacy: a metaanalysis. Anxiety Stress Coping. 2016;29(4):367-86. doi: 10.1080/10615806.2015.1058369

20. Freitas CPP, Silva CSC, Damásio BF, Koller SH, Teixeira MAP. Impact of job-related well-being on the relationship of self-efficacy with burnout. Paidéia. 2016;26(63):45-52. doi: 10.1590/1982-43272663201606

21. Consiglio C, Borgogni L, Vecchione M, Maslach C. Self-efficacy, perceptions of context, and burnout: a multilevel study on nurses. Med Lav [Internet]. 2014 [cited 2018 Apr 13];105(4):255-68. Available from: https://pdfs.semanticscholar.org/e0a1/ e0b385961423a385f1ee93a14605ecc27875.pdf

22. Yu JH, Chae SJ, Chang KH. The relationship among self-efficacy, perfectionism and academic burnout in medical school students. Korean J Med Educ. 2016;28(1):49-55. doi: 10.3946/kjme.2016.9 
23. Maslach C, Jackson SE. The measurement of experienced burnout. J Occup Behavior. 1981;2(2):99-113. doi: 10.1002/job.4030020205

24. Lautert L. O desgaste profissional: estudo empírico com enfermeiras que trabalham em hospitais. Rev Gaúcha Enferm [Internet]. 1997 [cited 2018 Apr 13];18(2):133-44. Available from: https://seer.ufrgs.br/RevistaGauchadeEnfermagem/article/view/4140

25. Tamayo RM. Relação entre a síndrome de Burnout e os valores organizacionais no pessoal de enfermagem de dois hospitais públicos [dissertação]. Brasília: Universidade de Brasília; 1997.

26. Koller SH, Camino C, Ribeiro J. Adaptação e validação interna de duas escalas de empatia para uso no Brasil. Estud Psicol. 2001;18(3):43-53. doi: 10.1590/S0103-166X2001000300004

27. Davis MH. Measuring individual differences in empathy: evidence for a multidimensional approach. J Pers Soc Psychol. 1983;44(1):113-26. doi: $10.1037 / 0022-3514.44 .1 .113$

28. Damásio BF, Freitas CPP, Koller SH. Occupational Self-Efficacy Scale - Short Form (OSS-SF): Adaptation and evidence of construct validity of the Brazilian version. Rev Bras Orient Prof [Internet]. 2014 [cited 2018 Apr 13];15(1):65-74. Available from: http://pepsic.bvsalud.org/scielo. php?script=sci_arttext\&pid=S1679-33902014000100008\&lng=pt\&nrm=iso\&tlng=en

29. Rigotti T, Schyns B, Mohr G. A short version of the occupational self-efficacy scale: structural and construct validity across five countries. J Career Assess. 2008;16(2):238-55. doi: 10.1177/1069072707305763

30. Hosmer DW, Lemeshow S. Applied Logistic Regression. 2nd ed. New York: John Wiley \& Sons; 2000.

31. Pereira SS, Teixeira CAB, Reisdorfer E, Gherardi-Donato ECS, Juruema MF, Cardoso L. Burnout in nursing professionals: associations with early stress. Br J Ment Health Nurs. 2015;4(6):267-75. doi: 10.12968/bjmh.2015.4.6.267

32. Schaufeli WB, Bakker AB, Hoogduin K, Schaap C, Kladler A. On the clinical validity of Maslach burnout inventory and the burnout measure. Psychol Health. 2001;16:565-82. doi: 10.1080/08870440108405527

33. Carlotto MS, Câmara SG. Propriedades psicométricas do Maslach Burnout Inventory em uma amostra multifuncional. Estud Psicol. 2007;24(3):325-32. doi: 10.1590/S0103-166X2007000300004

34. Limeira PC, Seiffert OMLB, Ruiz-Moreno L. O que a literatura científica e os projetos político-pedagógicos revelam sobre a qualidade da educação superior em enfermagem? ABCS Health Sci. 2015;40(3):276-85. doi: 10.7322/abcshs.v40i3.808

35. Maslach C, Leiter MP. New insights into burnout and health care: strategies for improving civility and alleviating burnout. Med Teach 2017;3(2):160-3. doi: 10.1080/0142159X.2016.1248918

36. Lamothe M, Boujut E, Zenasni F, Sultan S. To be our not to be empathic: the combined role of empathic concern and perspective taking in understanding burnout in general practice. BMC Fam Pract. 2014;15:15. doi: 10.1186/1471-2296-15-15

37. Naczenski LM, De Vries JD, van Hooff MLM, Kompier MAJ. Systematic review of the association between physical activity and burnout. J Occup Health. 2017;59(6):477-94. doi: 10.1539/joh.17-0050-RA

38. Dyrbye LN, Satele D, Shanafelt TD. Healthy exercise habits are associated with lower risk of burnout and higher quality of life among U.S. medical students. Acad Med. 2017;92(7):1006-11. doi: 10.1097/ACM.0000000000001540

39. Dieser RB, Edginton CR, Ziemer R. Decreasing patient stress and physician/medical workforce burnout through health care environments: uncovering the serious leisure perspective at Mayo Clinic's Campus in Rochester, Minnesota. Mayo Clin Proc. 2017;92(7):1080-7. doi: 10.1016/j.mayocp.2017.03.017 